\title{
The Dynamic of Flourishing: What is The Role of Silaturrahim For Survivor of Disasters?
}

\author{
Etti Isnaini ${ }^{1}$, Siti Urbayatun ${ }^{2}$ \\ \{ettiisnaini.april@gmail.com ${ }^{1}$, siti.urbayatun@psy.uad.ac.id ${ }^{2}$ \}
}

Master Students on Professional Psychology of Ahmad Dahlan University, Yogyakarta ${ }^{1}$

Faculty of Psychology, Ahmad Dahlan University, Yogyakarta

\begin{abstract}
Flourishing is one of the concepts in positive psychology that explains a person's condition that shows optimal development, a condition when all the functions within oneself are working well. This study is a qualitative phenomenological study with four survivors of the Imogiri Bantul flood in 2017 and 2019 as respondents. Data were analyzed using content analysis. Criterion sampling was employed. The findings showed that respondents' initial psychological impact was centered on fear of the future because the current carried all their belongings. After evacuating and gathering with other survivors to seek help, respondents felt more optimistic and excited about facing the future (positive emotion). Survivors also continued working on college assignments with existing facilities (engagement), doing many activities with the community, starts to meet people more frequently (i.e., friends) even though they rarely met before. Other than, survivorsto seek help neighbors (relationship), have more appreciation towards life, interpret life in a more caring way, and more grateful for the family's safety (meaning), begins to focus again to college, as well as be more active in activities in the environment (accomplishment). Factors that influence flourishing include the attention of family, friends, and neighbors during and after the flood. The social support provided by family and relatives by visiting others (silaturrahim) increases survivors' happiness and optimism in living life after the disaster.
\end{abstract}

Keywords; Flourishing, Flood survivors, Silaturrahim.

\section{Introduction}

Based on a study by Habibah et al. [1], the Imogiri region was one $f$ the area that was quite severely affected by the flood in 2017, causing various psychological problems such as depression, anxiety, stress, and somatization to arise. The flood that struck Imogiri in 2019 was even higher than in 2017. The height of the water during the earlier flood did not reach inside the residential houses, but the latest flood reached chest level. Consequently, several students living in that area experiences the psychological impact of being survivors of the flood.

Habibah et al. [1] stated that flood could influence survivors' life satisfaction. A person needs a degree of resilience to allow him or her to continue growing and be productive after becoming a victim to flood [2]. Before a person can grow the strength to continue to survive and be productive in life after being affected by a disaster, he first needs to interpret his life's journey positively.

Although there are differences between the concepts of flourishing and happiness, the two terms can be used to describe the quality of a person's life in a certain period or to evaluate one's life as a whole [3]. According to Aristoteles [4] flourishing relates to the virtues in life, happiness based on meaningful life achievement, as well as accomplishments of developmental goals (i.e., 
doing what is supposed to be done). These factors are the keys to having a good life. Keyes [5] described individuals who flourished as people who show ultimate mental wellbeing, conceptualized through a combination of excellent emotional, psychological, and social wellbeing. This concept of wellbeing can be achieved from the social environment of an individual, such as their interpersonal relations.

One form of social relations carried out daily by Muslims is silaturahmi. The concept of silaturrahmi came from the Arabic term "silaturrahim" which refers to the strengthening of relationships between relatives or family that is based on affection [6]. Furthermore, silaturrahim concretely can be realized in the form of doing good (Ihsan), providing material assistance, as well as maintaining and increasing affection for fellow relatives [6]. The attitude of affection shown by helping each other, visiting, and helping in kindness can bring happiness to those involved in silaturrahim.

Happiness and positive relations from silaturrahim appear during the stage when individuals' life is developing towards a more flourished state. Research on the use of community networks as a circle of social support by Guarnacci [7] showed that religion is one of the essential aspects of managing human resources when dealing with disasters in Indonesia. The results showed that the similarity of religion in Aceh, namely Islam, became one of the ties as a social capital for the community to overcome the impact of disasters. The existence of activities to help each other and maintain goodness with fellow Muslims, allows survivors in Aceh to develop a better life. Individual efforts to flourish and achieve happiness after experiencing a loss due to disasters lead to a flourishing life.

Flourishing has been studied using various methods and across a diverse population, such as one done in Turkey by Akin \& Akin [8] which found internal factors (i.e., coping competence, mindfulness) to play a significant role in subjective wellbeing and flourishing. Other internal factors were investigated by Catalino\& Fredrickson [9], who discovered that routine activities could increase flourishing. Another researcher experimented by giving treatment in the form of coaching for soccer athletes. The experiment revealed that the treatment contributes to maintaining mental wellbeing and flourishing, as well as prevents the development of mental illness [10]. The presence of factors in positive psychology (i.e., flourishing, hope, and optimism) could decrease the number of workers who experience burn-out [11].

This study involves female survivors of disasters as participants to explore their dynamic in resolving issues, flourishing process, and interaction with others (Silaturrahim) as a protective factor that is similar to the concept of social support.

\section{Flourishing: A Concept of Continuous Growth in Human's Happiness}

Happiness is the nature of every human being, including university students. Everyone, regardless of status and problems, wants to feel happy and at peace [12]. In reality, not everyone can achieve happiness on a daily basis. The existence of problems in life as well as issues beyond one's control (i.e., flood) can impact a person's physical and psychological condition. A study by Habibah et al. [1] showed that flood could influence the life satisfaction of the survivors.

According to Aristoteles [12] flourishing relates to the virtues in life, happiness based on meaningful life achievement, as well as accomplishments of developmental goals (i.e., doing what is supposed to be done). These factors are the keys to having a good life. Keyes[9] described 
individuals who flourished as people who show ultimate mental wellbeing, conceptualized through a combination of excellent emotional, psychological, and social wellbeing.

Flourishing refers to life journeys that went well [13]. According to Seligman [13], flourishing is a combination of feeling good and functioning effectively as a person. Based on the definitions, students who can continue living their life well, maintain a good feeling, and function effectively to cultivate his or her strength and productivity, has achieved the highest level of happiness. Additionally, Seligman [13] also stated that flourishing is a picture of a complete life that is dedicated to garnering beneficial goods through meaningful daily activities.

Essentially, everyone can achieve happiness. However, people can sometimes feel depressed and stressed when they have to recover and return to performing productive activities following a disaster. College students, as part of the community, also shows a different role and status after becoming survivors of a disaster. Disaster is a negative experience that impacts a person's psychological condition. People who experience uncontrolled negative experience could become passive, not putting any effort to improve their conditions in the future. These types of people also have cognitive issues: problems in seeing that their action will only succeed when they really do it [14].

Individuals who, despite being truly helpless was able to overcome the negative experience, reported that their primary key for success was committing to continue living. People who viewed negative experience or disasters as an inhibitor to life tend to have a more severe level of helplessness. On the other hand, people who saw the negative experience as being temporary and reported striving to continue living will be much happier [14]. According to Wortman \& Conway [15], social support can be achieved from partners, family members, and friends. Additionally, Johnson \& Johnson [4] also stated that receiving social support from significant others in times of need is significantly effective for reducing one's adverse psychological impact. Orford[16] also mentioned that the type of family support is typically given in the form of showing concern and intimacy. Receiving these treatments based on mutual affection can help one's social adjustment and mental development.

\section{METHOD}

The research used phenomenology, a qualitative method, and involved four survivors of the Imogiri Bantul flood which occurred in 2017 and 2019. The data analysis technique used was content analysis, while thesampling used was criterion sampling. The main instrument of this study is in-depth interviews with key informants. The interview guide refers to the aspects of flourishing created by Seligman [17], named after PERMA. Informants were obtained by screening survivors who met the criteria of havinga moderate and high flourishing level based on the self-report. In-depth interviews were conducted after the screening process. Data validity used triangulation of data sources with people who understand the life of the informant, including family and friends.

\section{RESULTS}


The results showed that directly following the incident, the psychological impact of survivors took the form of fear of the future due to their wealth being carried away by the current. After being evacuated, getting the chance to meet other survivors, and receiving help, the subjects became more optimistic, passionate about facing the future (positive emotion), motivated to continue carrying out their role as students with whatever existing facilities (engagement), take part in community activities, build closer and more intensive social relationships with other people such as friends who were willing to provide assistance despite having rarely met before, help and ask help from neighbors (relationship), treasure their life more than before the incident, place more meaning in life by caring and being grateful for his or her family's safety (meaning), begin focusing on college once again, and stay active in and around the environment (accomplishment). Factors that influence the flourishing of survivors are the attention of family, friends, and neighbours during and after the flood. The social support provided by family and relatives in the form of visiting survivor's home, otherwise known as silaturrahim, leads them to become happier and more optimistic in facing life after a disaster.

\section{DISCUSSIONS}

Humans are social creatures, who need other human beings to be able to help each other, support, and work together to meet their needs in the world. Therefore, in Islam, silaturrahim is very important. Islam teaches that establishing good relations with others is a sign of a servant's submission to his Lord. This is evident from the words of the Prophet: "Allah'azzawajalla said: I am the Merciful (Ar-Rahman), I created the womb, and I derived its name from my name. So, whoever maintains its relations, Iwill maintain my relationship with them, and whoever cuts off its relations, I willcut them off"(Musnad Ahmad Ibn Hanbal). Silaturrahim as a sign of faith which is evident in the following hadith: "Whoever believes in Allah and the Last Day, let him speak goodness or remain silent. Whoever believes in Allah and the Last Day, let him honour his neighbour. Whoever believes in Allah and the Last Day, he should continue to maintain thesilaturrahim."[17].

Based on the two hadiths above, it appears that Allah SubhanahuwaTa 'àlā(SWT) commands each of His servants to maintain the unity of fellow human beings, one of which is throughsilaturrahim. Silaturrahim makes it easier forone to help a family or a relative who is in need. Flood survivors are people who require help. Hence, Islam teaches to help one another in the face of difficulties. It is evident that flood survivors in Imogiri feel aided and feel a decrease of the psychological burden when relatives, friends, and neighbours come to assist through their physical presence and helping hand, money, and emotional support.

Helping families and relatives who are experiencing difficulties are considered as an alm (sadaqah) in Islam. Allah SWT promises merit and ease for His servants who extend friendship and facilitate the affairs of his or her brother or sister. The promise was made in the words of the Allah's Messenger, narrated by Abu Hurairah: "Anyone who is pleased that his sustenance is expanded, and his age extended should do kindness to his near relatives." [19]. Also, Allah SWT promises to bring paradise to His servants who can maintain silaturrahim with each other, as stated in the following hadith "You worship Allah and do not associate anything with Him, establish prayers, perform alms, and retainsilaturrahim." [19]. 
Some of the above traditions emphasize that Islam strongly encourages its followers to build silaturrahim among themselves. Silaturrahim not only provides blessings and happiness for the who initiates or visits. People who are being visited will also feel happy when they find that their family, friends, or neighbours still care. Flood survivors also felt that the presence of family and relatives during and after the disaster became a reinforcement and uplifted their happiness, providing a sense of being cared for due to having compassionate relatives. The survivors felt relieved of their burden and were optimistic that, despite the disaster, they are not alone and have lots of relatives.

In addition to what has been stated above, the wisdom and virtue of silaturrahim are that it can increase empathy and deter human beings from selfishness. According to Hakim[17], Islam teaches that social life is essential, through relationships between human beings, a servant gives birth to social rights and obligations. The rights and obligations include helping and respecting one another. Silaturrahimallows human beings to understand the difficulties of others, hence building empathy and care for those who experienced a disaster. This form of emotional support leads flood survivors to be more optimistic and confident in dealing with their psychological burdens.

\section{Psychological Effects of Silaturrahim}

Every human being requires security, harmony, and stability within the society, as well as the need to maintain a balance of their social functions within a community. These needs can be met if there is good social support from their environment. The existence of social support in the face of difficulties can help reduce psychological burdens which allow individuals to feel that he or she is not alone in facing the problem. Silaturrahim is one way to acquire social support when facing problems. The more one builds a reciprocal relationship; the more people can provide social support that may benefit in the future.

Mariana\&Nurmilah [18] mentioned that the wisdom of silaturrahim isthat it brings to bring happiness. Furthermore, one of the benefits of silaturrahim activity is that it allows both parties to love each other and build a feeling of empathy. People who do and receive good deeds will feel happy. When an individual feel happy from what he has received and given, then it is said to he or she has achieved a flourishing life.

It was previously explained that silaturrahimprovides much-needed support. Silaturrahim directly allows both parties to share stories and experiences about what happened as well as what one requires. When individuals deliver news and information to each other, the interaction can give birth to forms of social support between the two. According to Johnson and Johnson [18], social support directly or indirectly affects one's productivity, improve psychological well-being, physical health, and self-control. According to Orford [14], feeling accepted and respected in social support is an essential element of bringing feelings of happiness and togetherness to the recipient.

Additionally, Corno[19] stated that someone who has high social support is able to change their response to stress. Imogiri flood survivors are very vulnerable to a decrease of life productivity and psychological well-being. They are very vulnerable to psychological stress and trauma. Social support, in this case, a visit from friends and relatives, is expected to reduce these negative impacts. 
How silaturrahim that enables social support can influence happiness and its flourish to one's peak, is explained in the following scheme:

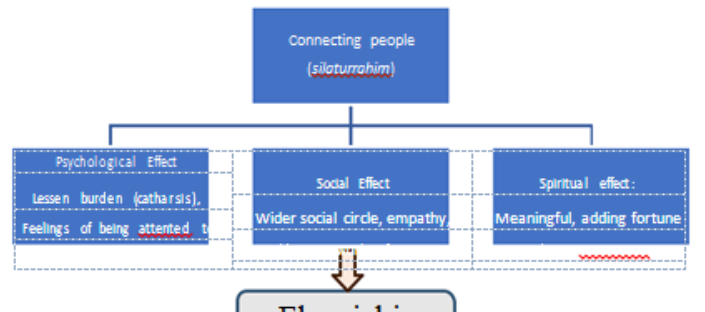

Flourishing

Social support has been given to flood survivors in Imogiri through silaturrahimof their closest friends and relatives. Islam recommends Silaturrahim because it can provide positive benefits to both parties involved. Silaturrahim allows the survivors to feel touched and happy as they consider it a form Allah's love, who has given the survivor the care and attention of other people in the face of disaster. The care of family and relatives is, although, a result of maintaining good relations.

Concern and attention given duringsilaturrahimallow feelings of happiness which in turn improves the mental condition of survivors, subsequently helping increase piety to Allah. According to Aristotle [4], individuals who acquire happiness from meaningful life achievements and can fulfil or achieve all should be achieved in each stage of life are said to have a high level of flourishing. Silaturrahim can foster feelings of being cared for, loved, as well asreduce the burden or psychological problems of individuals, indicating that the topic should be further scientifically explored.

\section{ACKNOWLEDGMENT}

The research has been supported by Directorate of Research and Community Service of the Directorate General of Research and Technology Strengthening Development of the Ministry of Research, Technology and Higher Education, with the Research Contract Number: PTM014/SKPP.TT/LPPM UAD/III/2019.

\section{REFERENCES}

[1] R. Habibah, S. D. Lestari, S. K. Oktaviana, and F. Nashori, "Resiliensi pada Penyintas Banjir Ditinjau dari Tawakal dan Kecerdasan Emosi," J. Psikol. Islam dan Budaya, vol. 1, no. 1, p. 29, 2018.

[2] L. D. Mccubbin, H. I. Mccubbin, W. Zhang, L. Kehl, and I. Strom, "Relational Well-being: An Indigenous Perspective and Measure," Fam. Relat., vol. 62, no. 2, pp. 354-365, 2013.

[3] D. Blickhan, Positive Psychologie: Ein Handbuch für die Praxis. 2015.

[4] F. Psikologi, U. Gadjah, and M. Yogyakarta, "The Effectivenessofthe Religious Coping Trainingto Enhance" Sebagai negara yang memiliki banyak gunung aktif, Indonesia menjadi negara yang rawan terhadap terjadinya letusan gunung berapi . Pada tahun 2010 , Daerah Istimewa Yogyakarta dan Jawa Teng," vol. 5, no. 1, pp. 95-110. 
[5] N. Effendy, "Konsep flourishing dalam psikologi positif: Subjective well-being atau berbeda?," Semin. Asean Psychol. Humanit., no. 2004, pp. 326-333, 2016.

[6] M. D. H. Al Ghozali, "Silaturrahim Perspektif Filsafat Islam," Dinamika, vol. 1, no. 1, pp. 51-66, 2016.

[7] U. Guarnacci, "Joining the dots: Social networks and community resilience in post-conflict, postdisaster Indonesia,” Int. J. Disaster Risk Reduct., vol. 16, pp. 180-191, 2016.

[8] A. Akin and U. Akin, "Mediating role of coping competence on the relationship between mindfulness and flourishing," Suma Psicol., vol. 22, no. 1, pp. 37-43, 2015.

[9] L. I. Catalino and B. L. Fredrickson, "A Tuesday in the Life of a Flourisher: The Role of Positive Emotional Reactivity in Optimal Mental Health,” Emotion, vol. 11, no. 4, pp. 938-950, 2011.

[10] M. Schotanus-Dijkstra, C. H. C. Drossaert, M. E. Pieterse, B. Boon, J. A. Walburg, and E. T. Bohlmeijer, "An early intervention to promote well-being and flourishing and reduce anxiety and depression: A randomized controlled trial," Internet Interv., vol. 9, no. April, pp. 15-24, 2017.

[11] M. H. Vetter, M. K. Vetter, and J. Fowler, "Resilience, hope and flourishing are inversely associated with

Burnout among members of the Society for Gynecologic Oncology "Gynecol, Oncol, Repots, vol. 25 no. June, pp. 52-55,2018

[12] A. E. Clark and C. Senik, "Is happiness different froflourishing? Cross-country evidence from the ESS,” Rev. Econ. Polit., vol. 121, no. 1, pp. 17-34, 2011.

[13] C. Behavioral and T. Book, "Seligman Authentic Happiness ," vol. 1, no. 8, pp. 1-2, 2005.

[14] A. Seligm, "Flourish-Positive Psychology and Positive Interventions_The Tanner Lectures on Human Values," 2010.

[15] S. Support and S. Capital, "Positive Psychology” vol. 3, pp. 1-30, 2016.

[16] A. Natale, S. Di Martino, F. Procentese, and C. Arcidiacono, "De-growth and critical community psychology: Contributions towards individual and social well-being," Futures, vol. 78-79, no. December 2015, pp. 47-56, 2016.

[17] B. M. E. Mosely, "Martin e." 1937.

[18] J. K. Johnson et al., "Recruitment and baseline characteristics of the Community of Voices choir study to promote the health and well-being of diverse older adults," Contemp. Clin. Trials Commun., vol. 8, no. September, pp. 106-113, 2017.

[19] G. Corno et al., "Effect of a web-based positive psychology intervention on prenatal well-being: A case series study," Women and Birth, 2017.

[20] Hakim, K.A. 1986. Hidup yang IslamiMenyeharikanPemikiranTransendental (Aqidah dan Ubudiah). Jakarta: CV. Rajawali.

[21] Mariana, A., dan Nurmilah, M. 2012. InilahPesanPenting di BalikBerkah\&ManfaatSilaturahmi. Bandung: Ruang kata.

[22] Al-Banna, H., \& Nawawi, I. 2007. Al-Ma'tsurat\&HaditsArba'in. Jakarta: Gema Insani 
